\title{
Inventory of refugia plants potentially medicinal in the agricultural area of Plandaan Subdistrict, Jombang Regency, East Java Province
}

\author{
Anggun Wulandari, Fadhilatus Syarifah
}

Department of Biology Education, Faculty of Education, Universitas KH. A. Wahab Hasbullah, Jombang, Indonesia

ARTICLE INFO

Article History

Received:

June 30, 2021

Accepted: Augustus 14, 2021

Published: Augustus 29, 2021

Keywords:

inventory,

medicine,

Plandaan subdistrict,

refugia

Cite this:

J. IIm. Pertan., 2021, 18 (1) 12-19

DOI:

https://doi.org/10.31849/jip.v18i1.7158

\section{ABSTRACT}

Agricultural and plantation areas dominate the Plandaan subdistrict, so the majority of the livelihoods of its residents are engaged in agriculture. In practice, in addition to using pesticides, crop pest control in the Plandaan subdistrict is to make use of refugia plants. The refugia technique is economical and environmentally friendly because it does not use synthetic chemicals that damage the environment. In addition to acting as natural pest control, refugia plants are also known to have potential as medicines. This study aimed to inventory or collect medicinal plants refugia in the agricultural area of the Plandaan subdistrict. This study used descriptive explorative methods. Data collection techniques were carried out through observation and directly documenting species of refugia plants with potential drugs found in the area of observation plots. In this study, the subject was a potentially medicinal refugia plant found on an observational plot with a plot size of $10 \times 10$ meters. The observations were three plots of agriculture fields and three plots of telajakan (open space). The frequency of refugia plants found from the study on the plot of agriculture fields as many as 1035 plants, while in the plot of telajakan as many as 1007 plants consisting of 37 types of species that each has different medicinal potentials, such as heat and fever lowering, treating cough, flu, skin diseases, and wounds. Agriculture field plots had more frequency of potentially medicinal refugia plants than telajakan plots.

\section{INTRODUCTION}

Plandaan is one of the sub-districts in Jombang Regency, East Java, Indonesia located at $07^{\circ} 20^{\prime}$ $011^{\prime \prime}-07^{\circ} 45^{\prime}$ O1" South Latitude and $05^{\circ} 20^{\prime} 011^{\prime \prime}$ - $05^{\circ} 30^{\prime}$ O1" East Longitude. Located in the northwesternmost part, in the north bordered by Kabuh Subdistrict, the south is bordered by Megaluh Subdistrict, Ploso Subdistrict borders the east, and in the west, it borders Nganjuk Regency (BPS Kab. Jombang, 2019). Plandaan subdistrict is dominated by agricultural and plantation areas, so the majority of the livelihoods of its residents are engaged in agriculture, and almost all farmers in Plandaan subdistrict use pesticides in conducting pest and disease control. In crop cultivation activities, the presence of pest attacks and uncontrolled diseases can decrease production and even lead to crop failure; therefore, it is necessary to use

\footnotetext{
*Corresponding Author

E-mail: anggun.4w@gmail.com
}

pesticides (Kodir, 2019). However, behind all its advantages, pesticides also negatively impact human health and the environment. As an alternative, one pest control in plants in the Plandaan subdistrict is to use ornamental plants known as refugia.

Refugia plants are generally only known as flowering plants in the cultivation plant area. However, according to experts, the definition of refugia plants are some types of plants that can provide shelter, feed sources, or other resources for natural enemies such as predators and parasitoids (Muliani et al., 2020). Refugia plants are generally planted on the mound's edge or outside the plant in a long and striking flowering. Planting and utilizing plants that can become natural enemy habitats is the main alternative in integrated plant management because it has a high effect on biodiversity and insect abundance (Luen et al., 2013). In addition, this refugia technique is more economical and certainly more environmentally friendly. 
Refugia plants can be ornamental plants, weeds, or vegetables. According to Allifah et al. (2019), some studies mention the types of ornamental plants that have the potential as refugia are sunflowers (Helianthus annuus), paper flowers (Zinnia peruviana), kenikir (Cosmos caudatus), cempasuchil (Tagetes erecta), and several other types of flowers. Some weeds derived from the family Asteraceae such as billygoat-weed (Ageratum conyzoides) and cobblers pegs (Bidens pilosa L.) can also be used as refugia plants (Muliani et al., 2020). Widiastuti (2000) reported that the insect family Coccinellidae prefers wild plants from the family Asteraceae, such as Eupatorium and Bidens. Sukaromah and Yanuwiadi (2006) suggest that some plant parasites prefer to live on weeds and will attack cultivated plants if the weeds do not exist.

Refugia plants that have a role as an alternative to control pests, on the other hand, also have potential as a medicine. Most people do not know the benefits of refugia plants (herbs) for health because people are more familiar with chemicals. Kartika (2017) stated that medicinal plants are a type of plant that, in certain parts of both roots, stems, skin, leaves, and excretion results are believed to heal or reduce pain. Refugia plants that are deliberately planted and grow wild in agriculture fields may also have great potential as a medicinal plant efficacious. The meaning of efficacious drugs is to contain active substances that can serve to treat certain diseases. Therefore, potential medicinal plants contain compounds or active ingredients with medicinal properties (Rubiah et al., 2015). Therefore, to know the type of plants refugia potentially drugs in the Plandaan subdistrict, inventory activities need to be carried out to maintain, preserve, and utilize the role of such plants for the continuity of organisms.

\section{MATERIALS AND METHODS}

This research was a combination of explorative and descriptive. The location of the research was in the agricultural area of the Plandaan Subdistrict, Jombang Regency. The subject was potentially medicinal of refugia plant found on an observational plot. Data collection techniques used random sampling techniques with a plot size of $10 \times 10$ meters, covering agriculture fields and telajakan ${ }^{1}$ areas, were carried out three replications. The plots of observations taken from this study were three plots of agriculture fields and three plots of telajakan. The agriculture field and telajakan observation plots were taken in

\footnotetext{
${ }^{1}$ The local term for green open spaces along the village streets, close to paddy fields
}

different and random areas of agriculture, respectively. The samples of agriculture fields in this study were the papaya farming area of Plandaan village, the banana farming area of Bangsri village, and the corn farming in Pojok Klitih village. While the samples of telajakan plots in the same village with agriculture fields.

The research method was conducted by direct observation. The data collected include plant frequency, plant images, scientific names, local names, and medicinal potential found in plants. This study used descriptive data analysis techniques, which were techniques whose data were collected in the form of frequency (amount) of refugia plants with potential medicines. Refugia plants that can be medicinal on each observation plot were calculated and then carried out species identification.

\section{RESULTS AND DISCUSSIONS}

The agriculture field plot was an observation plot taken in the agriculture field, while the telajakan plot is a field located on the left and right side of the road, usually slightly sloping down towards the paddy field area. Figures 1a and $1 \mathrm{~b}$ are examples of an agriculture field plot and a telajakan plot, respectively.

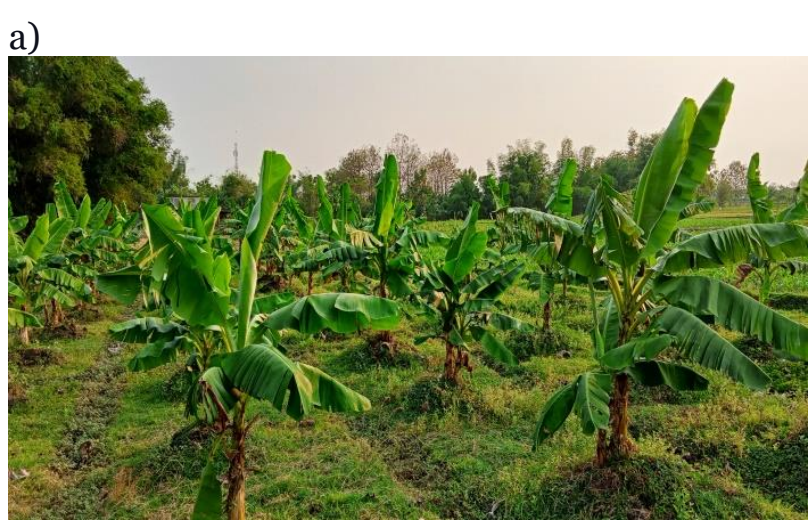

b)

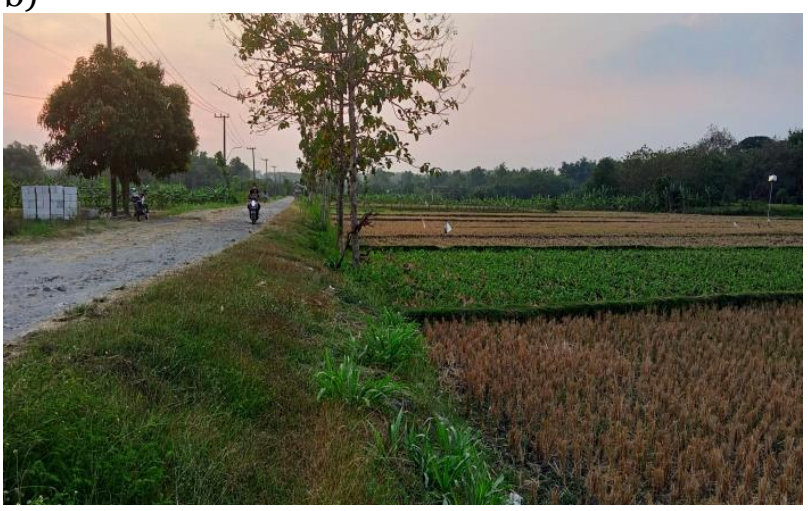

Figure 1. Picture of a) agriculture field plot in banana farming in Bangsri village, and b) Telajakan in Plandaan village 
Table 1. Frequency of refugia plants found in observation plots

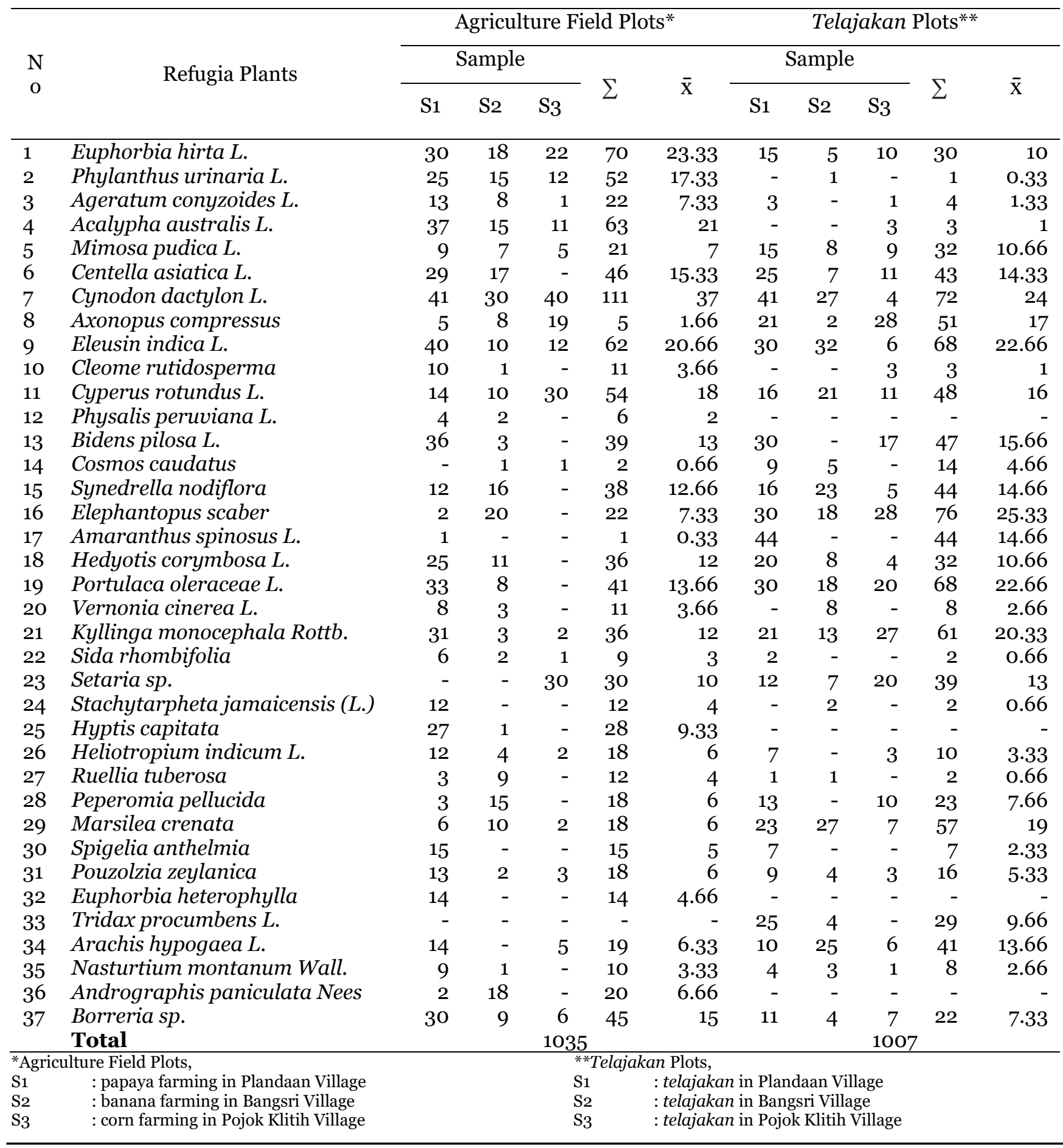

Refugia plants in all observation plots have different frequencies and types of plants. In agriculture field plots, refugia plants had more frequency than refugia plants on the plot of telajakan. The plot in agriculture fields had a frequency of 1035 plants, while the plot telajakan frequency was 1007 plants. The most common refugia plant found in agriculture field plots was Cynodon dactylon L. with total 111 plants and an average of 37 plants, and the least found refugia plant was Amaranthus rotundus
L. because there was only one plant from three sites of agriculture field. Then, in the telajakan plot, the most commonly found refugia plant type was Elephantopus scaber, with 76 plants. At the same time, the least refugia plant found in the telajakan plot was Phyllanthus urinaria L., with a plant count of one plant. The types of refugia plants found on the observation plot were diverse. The most widely found plants were grass and herbaceous. 
Many types and high survival ability make the refugia plants widely found in the agricultural area of the Plandaan Subdistrict. In addition, environmental factors are also the cause of the diversity of types of refugia plants, including high rainfall in the Plandaan subdistrict makes the soil in agricultural areas lose. On the other hand, the content owned by rainwater, such as nitrates that are important for plant growth, can make plants fertile (Triadmodjo, 2008), thus causing refugia plants to grow efficiently and quickly.

The results showed 37 species of refugia plants found in the observation plot in the agricultural area of the Plandaan Subdistrict. Of the 37 species, there are only one species of plant known to have no medicinal potential, namely Axonopus compressus, known by the local name of elephant paitan grass. Although this plant had not been identified as having medicinal potential, it has been known for its benefits as natural breeding animal feed (ruminants) in Southeast Asia. It can also be used for landscaping landscapes, such as the landscape of the house's yard, football field, toll road park, office park, and grass factory park. Apart from the elephant paitan grass plant, 36 other refugia plants found on the observation plot have been recorded as potentially medicinal. These types of plants have medicinal potential that can be utilized for health.

Table 2. Types of refugia plants potentially as medicine in the agricultural area of Plandaan Subdistrict

\begin{tabular}{|c|c|c|c|c|}
\hline No. & Species Name & Local Name & Family & Drug Potential \\
\hline 1. & $\begin{array}{l}\text { Euphorbia } \\
\text { hirta L. }\end{array}$ & $\begin{array}{l}\text { Patikan } \\
\text { Kebo }\end{array}$ & Euphorbiaceae & $\begin{array}{l}\text { Treat laryngitis, bronchitis and asthma, } \\
\text { dysentery, gastritis, diarrhea, blood urination, } \\
\text { mammary glands and swollen breasts, eczema, } \\
\text { skin diseases/hives, and burns. }\end{array}$ \\
\hline 2. & $\begin{array}{l}\text { Phylanthus } \\
\text { urinaria L. }\end{array}$ & Meniran & Euphorbiaceae & $\begin{array}{l}\text { Jaundice, malaria, fever, epilepsy, cough, } \\
\text { dysentery, burns, crustaceans, acne, Tinea } \\
\text { versicolor, antibiotics, uric acid, kidney stones, } \\
\text { cancer, diabetes, rheumatism, hepatitis, } \\
\text { arthritis, and menstruation. }\end{array}$ \\
\hline 3 . & $\begin{array}{l}\text { Ageratum } \\
\text { conyzoides L. }\end{array}$ & Bandotan & Asteraceae & $\begin{array}{l}\text { As a stimulant, tonic, fever reliever } \\
\text { (antipyretic), antitoxic, eliminate swelling, stop } \\
\text { bleeding (hemostatic), menstrual straightener } \\
\text { (emmenagogue), urinary straightener } \\
\text { (diuretic), and fart straightener. }\end{array}$ \\
\hline 4. & $\begin{array}{l}\text { Acalypha } \\
\text { indica L. }\end{array}$ & $\begin{array}{l}\text { Anting- } \\
\text { Anting }\end{array}$ & Euphorbiaceae & $\begin{array}{l}\text { As an anti-inflammatory, antibiotic, urine } \\
\text { decay, astringent stops bleeding (hemostatic). }\end{array}$ \\
\hline 5 . & $\begin{array}{l}\text { Mimosa pudica } \\
\text { L. }\end{array}$ & Putri Malu & Fabaceae & $\begin{array}{l}\text { As a heat-lowering drug, eliminate insomnia, } \\
\text { phlegm cough, gout, rheumatism, chronic } \\
\text { bronchitis, herpes, and worms. }\end{array}$ \\
\hline 6. & $\begin{array}{l}\text { Centella } \\
\text { asiatica L. }\end{array}$ & Pegagan & Apiaceae & $\begin{array}{l}\text { Cleans blood, improves blood circulation, } \\
\text { lowers fever, prevents kidney stones, helps } \\
\text { improve brain memory, overcome cough, stops } \\
\text { bleeding and infections in already chronic } \\
\text { wounds. }\end{array}$ \\
\hline 7. & $\begin{array}{l}\text { Cynodon } \\
\text { dactylon L. }\end{array}$ & $\begin{array}{l}\text { Suket } \\
\text { Grinting }\end{array}$ & Poaceae & $\begin{array}{l}\text { Diabetes, stone urination, stimulating breast } \\
\text { milk, and minor injuries. }\end{array}$ \\
\hline 8. & $\begin{array}{l}\text { Axonopus } \\
\text { compressus }\end{array}$ & $\begin{array}{l}\text { Rumput } \\
\text { Gajah Paitan }\end{array}$ & Poaceae & $\begin{array}{l}\text { This plant is not yet known to have the potential } \\
\text { as a medicine, but it has benefited as a natural } \\
\text { breeding animal feed (ruminant) in Southeast } \\
\text { Asia. It can also be used for landscaping } \\
\text { landscapes, such as landscape yard houses, } \\
\text { football fields, toll road parks, office parks, and } \\
\text { grass factory parks. }\end{array}$ \\
\hline 9. & $\begin{array}{l}\text { Eleusin indica } \\
\text { L. }\end{array}$ & $\begin{array}{l}\text { Rumput } \\
\text { Belulang }\end{array}$ & Poaceae & $\begin{array}{l}\text { Typhoid fever, intestinal infections, diarrhea } \\
\text { and difficulty defecation, headaches, and } \\
\text { abdominal pain. }\end{array}$ \\
\hline 10. & $\begin{array}{l}\text { Cleome } \\
\text { rutidosperma }\end{array}$ & $\begin{array}{l}\text { Maman } \\
\text { Ungu }\end{array}$ & Capparidaceae & $\begin{array}{l}\text { Potentially as an anti-cancer, it contains a } \\
\text { group of potential anti-cancer compounds such } \\
\text { as alkaloids and flavonoids. }\end{array}$ \\
\hline
\end{tabular}




\begin{tabular}{|c|c|c|c|c|}
\hline No. & Species Name & Local Name & Family & Drug Potential \\
\hline 11. & $\begin{array}{l}\text { Cyperus } \\
\text { rotundus } L .\end{array}$ & Teki ladang & Cyperaceae & $\begin{array}{l}\text { Treats stone urination, skin diseases, stimulates } \\
\text { the production of breast milk, lowers fever, } \\
\text { whiteness. }\end{array}$ \\
\hline 12. & $\begin{array}{l}\text { Physalis } \\
\text { peruviana L. }\end{array}$ & Ciplukan & Solanaceae & $\begin{array}{l}\text { Treat worms and heat-lowering, diabetes, high } \\
\text { blood pressure, respiratory tract infections or } \\
\text { phlegm cough, gonorrhea, heart boosters, lung } \\
\text { disease, skin diseases (ulcers, ulcers), } \\
\text { rheumatism. }\end{array}$ \\
\hline 13 . & $\begin{array}{l}\text { Bidens pilosa } \\
\text { L. }\end{array}$ & $\begin{array}{l}\text { Ketul/ } \\
\text { Ajeran }\end{array}$ & Asteraceae & $\begin{array}{l}\text { Anti-inflammatory (anti-inflammatory), } \\
\text { antipyretic (lowering body temperature), and } \\
\text { antiseptic (substances that can inhibit or stop } \\
\text { the growth of microorganisms in living tissues). }\end{array}$ \\
\hline 14. & $\begin{array}{l}\text { Cosmos } \\
\text { caudatus }\end{array}$ & Kenikir & Asteraceae & $\begin{array}{l}\text { Antioxidants, overcome lousy breath, increase } \\
\text { appetite, increase immunity, overcome } \\
\text { diabetes, overcome stomach problems and } \\
\text { strengthen bones. }\end{array}$ \\
\hline 15 . & $\begin{array}{l}\text { Synedrella } \\
\text { nodiflora }\end{array}$ & Jotang Kuda & Asteraceae & $\begin{array}{l}\text { Overcoming infections caused by bacteria and } \\
\text { fungi, ulcers, acne, and skin infections, } \\
\text { antioxidants, overcoming seizures, as a } \\
\text { sedative, maintaining liver health, treating } \\
\text { inflammation, as a painkiller and lowering } \\
\text { fever, curing open wounds, overcoming heart } \\
\text { disease and asthma, overcoming hemorrhoids, } \\
\text { diabetes, diarrhea, and increasing sexual } \\
\text { hormones and fertility rates. }\end{array}$ \\
\hline 16. & $\begin{array}{l}\text { Elephantopus } \\
\text { scaber }\end{array}$ & $\begin{array}{l}\text { Tapak } \\
\text { Liman }\end{array}$ & Asteraceae & $\begin{array}{l}\text { Anti-cancer, antioxidant, anti-diabetic, } \\
\text { antimicrobial, antiseptic, anti-hepatotoxic, } \\
\text { maintain liver health, overcome diarrhea, anti- } \\
\text { inflammatory, antiplatelet, and cough. }\end{array}$ \\
\hline 17. & $\begin{array}{l}\text { Amaranthus } \\
\text { spinosus }\end{array}$ & Bayam Duri & Amaranthaceae & $\begin{array}{l}\text { As a fever reliever (antipyretic), urinary decay } \\
\text { (diuretic), phlegm decay (expectorant), } \\
\text { antidote, eliminate swelling, and blood } \\
\text { cleansing, there are flavonoid substances that } \\
\text { serve as antioxidants, antibacterial, and anti- } \\
\text { cancer agents. }\end{array}$ \\
\hline 18. & $\begin{array}{l}\text { Hedyotis } \\
\text { corymbosa L. }\end{array}$ & $\begin{array}{l}\text { Rumput } \\
\text { Mutiara }\end{array}$ & Rubiaceae & $\begin{array}{l}\text { Tonsillitis, bronchitis, goiter, pneumonia, } \\
\text { appendicitis, hepatitis, pelvic inflammation, } \\
\text { urinary tract infections, ulcers, ulcers, cancer } \\
\text { (lymphosarcoma) of the stomach and cervix, } \\
\text { breast cancer, rectum, fibrosarcoma, and } \\
\text { nasopharyng. }\end{array}$ \\
\hline 19. & $\begin{array}{l}\text { Portulaca } \\
\text { oleraceae L. }\end{array}$ & Krokot & Portulacaceae & $\begin{array}{l}\text { Heat-lowering (antipyretic), painkillers } \\
\text { (analgetic), diuretics, antitoxic, sedatives, blood } \\
\text { sugar lowering, antioxidants (vitamin C } \\
\text { deficiency), cardiotonic boosters, swelling } \\
\text { removers, and blood releases. }\end{array}$ \\
\hline 20. & $\begin{array}{l}\text { Vernonia } \\
\text { cinerea } L .\end{array}$ & Sawi Langit & Asteraceae & $\begin{array}{l}\text { Fever, heat, cough, dysentery, hepatitis, lack of } \\
\text { mood (neurasthenia), insomnia. }\end{array}$ \\
\hline 21. & $\begin{array}{l}\text { Kyllinga } \\
\text { monocephala } \\
\text { Rottb. }\end{array}$ & $\begin{array}{l}\text { Rumput } \\
\text { Kenop }\end{array}$ & Cyperaceae & $\begin{array}{l}\text { Able to fight cancer cells, detoxification that can } \\
\text { get rid of toxins in the body, lower high blood } \\
\text { pressure, overcome prostate problems, wound } \\
\text { healing in the skin, prevent the occurrence of } \\
\text { premature aging, for headaches, anti- } \\
\text { inflammatory, blood cleansing, and bronchitis. }\end{array}$ \\
\hline 22. & $\begin{array}{l}\text { Sida } \\
\text { rhombifolia L. }\end{array}$ & Sidaguri & Malvaceae & $\begin{array}{l}\text { Influenza, fever, tonsillitis, diphtheria, } \\
\text { glandular tuberculosis (scrofuloderma), colitis, } \\
\text { dysentery, jaundice, malaria, urinary stones, } \\
\text { gastric pain, bleeding hemorrhoids, vomiting }\end{array}$ \\
\hline
\end{tabular}




\begin{tabular}{llll}
\hline No. & Species Name & Local Name & Family \\
\hline & & & \\
& & & \\
& & & \\
23. & Setaria sp. & $\begin{array}{l}\text { Rumput } \\
\text { Setaria }\end{array}$ & Poaceae \\
24. & $\begin{array}{l}\text { Stachytarpheta } \\
\text { jamaicensis } \\
\text { (L) Vecut Kuda }\end{array}$ & $\begin{array}{l}\text { Bunga Ungu } \\
\text { Bahl }\end{array}$ & Verbenaceae
\end{tabular}

blood, worms, shortness of breath (bronchial asthma), rheumatism, toothache, canker sores, bitten by venomous insects, lack of appetite, difficulty defecating (constipation), late menstruation, and ulcers that never heal.

Healthy women after childbirth or menstruation, natural birth control drugs.

Overcome flu and cough, digestive problems such as indigestion, acid reflux, ulcers, constipation, slow digestion, and various diseases caused by oxidation stress, including cancer. In addition, treat inflammation of the liver (hepatitis A) and vaginal discharge (leukorrhea).

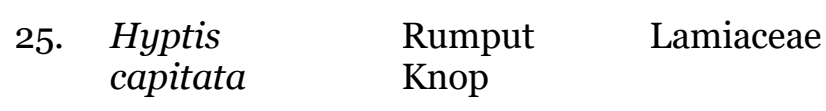

26. Heliotropium Sangketan Boraginaceae indicum $L$.

27. Ruellia

tuberosa

28. Peperomia pellucida

Tumpang

Air

Pletekan

Acanthaceae

29. Marsilea

crenata

30. Spigelia anthelmia

31. Pouzolzia zeylanica

32. Euphorbia heterophylla

33. Tridax procumbens $L$.

Semanggi Marsileaceae

Kemangi Loganiaceae

Cina

Daun Deras

Kate Mas

Songgolangit

Asteraceae

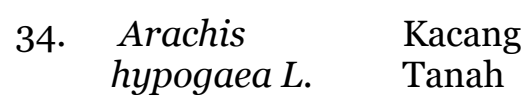

35. Nasturtium

Sawi Tanah Brassicaceae
Overcome diarrhea as a natural sedative, reduce heart palpitations, clean wounds, prevent infection, dry cough, and toothache; pain in infants, and seizures in children.

Pulmonary infections (pneumonitis), pulmonary abscess, pulmonary empyema, laryngitis, canker sores, diarrhea, dysentery, inflammation of the testicles, ulcers, inflammation of the festering skin, allergies, canker sores, new wounds, ulcers, eczema, and menstrual decay.

Treating diabetes and treating ulcers, treating coughs and flu, gonorrhea, stone urination, preventing UTIs (Urinary Tract Infections), warding off free radicals

Overcome fatigue, cataracts, lowering the risk of diabetes, heart disease, treating headaches, endurance body, kidney drugs, anti-cancer, acne drugs, and uric acid.

Treat infections of the urinary tract, tonsils, cough, and shortness of breath.

Eliminate acne, treat wound infections, and prevent aging.

As a launch of breast milk and antioxidants.

Reduce high blood pressure, stomach pain medications, and headache medications, facilitate defecation and overcome constipation. Relieve rheumatic symptoms and pain in the waist, act as an anti-inflammatory, antibiotic, and lower uric acid, reduce body fat, improve the immune system, improve blood sugar levels, strengthen liver function, and slow down the blood clotting process.

Lower the risk of coronary heart disease, lower cholesterol levels, and triglyceride levels, fight tuberculosis bacteria, lower high blood pressure, relieve hemophilia or tendency to bleed easily, whitish disease, and insomnia.

Inflammation of the airways, cough, tuberculosis, heat, measles, rheumatism, sore throat, hepatitis, ulcers, bruises, bloody wounds, snakebite, reduced. 


\begin{tabular}{|c|c|c|c|c|}
\hline No. & Species Name & Local Name & Family & Drug Potential \\
\hline 36. & $\begin{array}{l}\text { Andrographis } \\
\text { paniculata } \\
\text { Nees }\end{array}$ & Sambiloto & Acanthaceae & $\begin{array}{l}\text { As a hepatoprotective (protects liver cells from } \\
\text { toxic substances), bacteriostatic on } \\
\text { staphylococcus aureus, pseudomonas } \\
\text { aeruginosa, proteus Vulgaris, Shigella } \\
\text { dysenteriae, and escherichia coli, effective for } \\
\text { the treatment of infections, muscarinic effects } \\
\text { on blood vessels, effects on the scenic heart, } \\
\text { effects on cell respiration, choleretic, anti- } \\
\text { inflammatory, and antibacterial properties, } \\
\text { lower fever, may terminate the pregnancy and } \\
\text { inhibit the growth of placental platelets. }\end{array}$ \\
\hline 37. & Borreria sp. & Ketumpang & Asteraceae & $\begin{array}{l}\text { As a neutralizer of toxins, dysentery drugs, } \\
\text { burns, and ulcers. }\end{array}$ \\
\hline
\end{tabular}

Badrunasar \& Santoso (2016)

In its development, the refugia plant turns out to be potential as a medicine because it has active substance content for medicinal ingredients. It can be used to treat a variety of diseases, from minor diseases to chronic diseases. Some potential drugs contained in the type of refugia plant found in the observation plot were heat and fever lowering, treating cough, flu, skin diseases, wounds, nosebleeds, uric acid, sore throat, vomiting blood, indigestion, respiratory disorders, rheumatism, malaria, as an anticancer, antibiotics, antioxidants, antitoxins, antiseptics, antimicrobials, anti-infamous, overcoming stress and insomnia (Badrunasar \& Santoso, 2016), and many more. Plant parts that can potentially be medicinal include plants, namely roots, stems, leaves, fruits, seeds, flowers, and skin. According to Larassati and Kartika (2019), the leaf part is the most commonly used as medicine.

\section{CONCLUSIONS}

Agriculture field plots have more frequency of potentially medicinal refugia plants than telajakan plots. The most common refugia plant found in agriculture field plots was Cynodon dactylon L. The least found plant was Amaranthus rotundus L. While on the plot of telajakan, the most commonly found refugia plant was Elephantopus scaber and the least refugia plant found was Phyllanthus urinaria L. The potential medicinal refugia plant found in the observation plot numbered 37 species, and the most widely found were from grass and herbaceous plant. Several factors have contributed to the diversity of refugia plants found in the observation plot. Some of these factors were wide distribution, diverse species, high survivability, and environmental factors so that these plants were often found in the agricultural area of Plandaan Subdistrict. The potential of drugs contained in the type of refugia plants found in the observation plot was: as heat and fever lowering, treating cough, flu, skin diseases, wounds, nosebleeds, uric acid, sore throat, vomiting blood, indigestion, respiratory disorders, rheumatism, malaria, as an anticancer, antibiotics, antioxidants, antitoxins, antiseptics, antimicrobials, anti-infringers, overcoming stress and insomnia, and many more.

\section{REFERENCES}

Allifah AF, A. N., Rosmawati, R., \& Jamdin, Z. (2019). Refugia Ditinjau Dari Konsep Gulma Pengganggu Dan Upaya Konservasi Musuh Alami. Biosel: Biology Science and Education, $\quad 8(1), \quad 82$. https://doi.org/10.33477/bs.v8i1.849

Badan Pusat Statistik (BPS) Kabupaten Jombang (2019, Oct). Plandaan Subdistrict Geographical Location in 2016. BPS. https://jombangkab.bps.go.id/statictable/ 2019/10/16/3414/letak-geografiskecamatan-plandaan-2016.html.

Badrunasar, A., \& Santoso, H. B. (2016). Tumbuhan Liar Berkhasiat Obat. Forda Press

Kartika, T. (2017). Potensi Tumbuhan Liar Berkhasiat Obat Di Sekitar Pekarangan Kelurahan Silaberanti Kecamatan Silaberanti. Sainmatika, 14 (2), 89-99.

Kodir, A. (2016). Pengaruh Penggunaan Pestisida Nabati Terhadap Pertumbuhan Dan Hasil Padi Sawah Inpari 14 (Studi Kasus Pada Demplot Slptt Padi Sawah di Kabupaten OKU Selatan). Balai Pengkajian Teknologi Pertanian Sumatera Selatan

Larassati, A., \& Kartika, T. (2019). Inventarisasi Tumbuhan Berkhasiat Obat Di Sekitar Pekarangan Di Kelurahan Sentosa. In Jurnal Indobiosains, 1(2). https://doi.org/10.31851/indobiosains.v1i2 .3198

Luen, K., Wong, L., \& Reyes, J. H. D. L. (2013). ADB Sustainable Development Working 
Paper Series Addressing Planthopper Threats to Asian Rice Farming and Food Security: Fixing Insecticide Misuse ADB Sustainable Development Working Paper Series Addressing Planthopper Threats to Asian Rice Farming and F. Asian Development Bank, 27.

Muliani, S., Eriani, E., Halid, E., Kumalawati, Z., Budidaya, J., Perkebunan, T., Negeri, P., \& Correspondent, P. (2020). Inventarisasi Serangga Pada Tanaman Refugia Di Lahan Teaching Farm, Buludua. Agroplantae: Jurnal Ilmiah Terapan Budidaya Dan Pengelolaan Tanaman Pertanian Dan Perkebunan, 9 (1). https://doi.org/10.51978/agro.vgi1.97

Rubiah, Djufri, Muhibbuddin. 2015. Kajian Etnobotani Tumbuhan Obat Penyakit Kulit Pada Masyarakat Kabupaten Pidie. Jurnal Biologi Edukasi, 7 (1).

Steenis, van C.G.G.J. (2006). Flora. PT Pradynya Paramitha.
Sukaromah, \& Yanuwiadi, B. (2006). Preferensi Serangga Famili Coccinelidae untuk memilih kombinasi Tumbuhan Familia Asteraceae. Bioscientiae, 3(1), 30-38.

Tjitrosoepomo, G. (2013). Morfologi Tumbuhan. Gadjah Mada University Press

Tjitrosoepomo, G. (2014). Taksonomi Tumbuhan (Schizophyta, Thallophyta, Bryophyta, Pteridophyta). Gadjah Mada University Press

Tjitrosoepomo, G. (2016). Taksonomi Tumbuhan Obat-Obatan. Gadjah Mada University Press

Triatmodjo, B., 2008. Hidrologi Terapan. Beta Offset Yogyakarta.

Widiastuti, 2000. Uji Preferensi Serangga Coccinellidae pada Tanaman Famili Asteraceae. FMIPA. Universitas Brawijaya. Malang 